\title{
EFFECT OF COMMUNITY LEAD TOTAL SANITATION ON PERSONAL HYGIENE AND LATRINE OWNERSHIP
}

\author{
Indasah \\ Graduate Program in Public Health, School of Health Sciences \\ (STIKES) Surya Mitra Husada, Kediri
}

\begin{abstract}
BACKGROUND: Good personal hygiene with respect to human excreta disposal is important to prevent environmental pollution and diseases. Several strategies had been implemented, but thus far were not effective. A new method, namely Community Lead Total Sanitation (CLTS) had been developed to empower community participation in addressing personal hygiene and sanitation issues. This study aimed to determine the effect of community lead total sanitation on personal hygiene and latrine ownership.

SUBJECT AND METHODS: This study was a quasi-experimental, before and after with no control design, conducted in Kediri, East Java. A sample of 125 households was selected from 1258 households living in a rural area, Kediri, East Java. The dependent variables were personal hygiene with respect to human excreta disposal and good latrine ownership. These variables were measured by a questionnaire. The independent variable was Community Lead Total Sanitation program. This program was intended to empower community so that they are able to identify environmental factors affecting community health and solve this problem. Changes in the proportion of community members with good personal hygiene and good latrine ownership were tested by McNemar test.

RESULTS: The proportion of community members with good personal hygiene increased from $66(52.8 \%)$ before program to $84(67.2 \%)$ after program, and it was statistically significant $(\mathrm{p}=0.002)$. The proportion of community members with good latrine ownership increased from 66 (52.8\%) before program to $92(73.5 \%)$ after program, and it was statistically significant $(\mathrm{p}<0.001)$.

CONCLUSION: Community empowerment with Community Lead Total Sanitation is effective to improve personal hygiene with respect to human excreta disposal and to increase good latrine ownership.
\end{abstract}

Keywords: human excreta disposal, latrine, personal hygiene, Community Lead Total Sanitation 